\title{
Primary Sjögren-Larsson syndrome: report of a 10 years old girl with local edema and positivity of anti SS-A and anti SS-B autoantibodies
}

\section{Sindrome di Sjögren-Larsson primario: caso clinico di una bambina di 10 anni con edema locale e positività degli anticorpi anti SS-A e anti SS-B}

\author{
E. Shahi, C. Donati, M. Gattinara, I. Pontikaki, V. Gerloni \\ U.O. di Reumatologia dell'età evolutiva, Dipartimento di Reumatologia, \\ Università degli Studi di Milano, Istituto G. Pini
}

\section{RIASSUNTO}

La sindrome di Sjögren (SS) è una malattia autoimmune che colpisce con maggior frequenza gli adulti di sesso femminile. È poco comune nell'infanzia.

Si descrive il caso clinico di una bambina di 10 anni con positività del test di Schirmer, presenza di anticorpi anti SS-A e anti SS-B. La biopsia delle ghiandole salivari minori mostra infiltrato linfocitico periduttale ed ectasia dei dotti di quarto grado riferibile a S. di Sjögren.

La S. di Sjögren nei bambini è descritta in pochi casi in letteratura. Le manifestazioni cliniche potrebbero differire da quelle degli adulti, mentre alcuni dati di laboratorio potrebbero essere similari.

Reumatismo. 2011: 63 (2): 97-100

\section{INTRODUCTION}

jögren syndrome (SS) is a chronic au-

toimmune disease of unknown etiology most commonly seen in women (male/ female ratio 1/9) mainly in the fourth and fifth decades of life.

This syndrome is characterized by lymphocytic infiltration of exocrine glands resulting in xerostomia and keratoconjuctivitis sicca. It may occur alone (primary Sjögren syndrome) or in association with other autoimmune diseases (secondary Sjögren syndrome) such as rheumatoid arthritis, systemic lupus erythematosus or systemic sclerosis (1-5).

We describe a case of juvenile Sjögren syndrome in a 10-year-old girl who developed arthralgia, purpura and local edema of the dorsum of her feet.

\section{CASE REPORT}

A 10-year-old girl with recurrent arthralgia and swelling of her feet of seven month duration was referred to the Pediatric Rheumatology Clinic, G. Pini Hospital, Faculty of Medicine, University of Milan, for evaluation and treatment.

Since May 2008, almost every month, she suffered from symptomatic (painful) edema of feet and purpura, which remitted in 4-5 days without therapy.

A serum sample was tested for the presence of anti-SS-A and anti-SS-B antibodies (enzyme linked immunosorbent assay), ANA (anti nuclear antibody), Waaler Rose and rheumatoid factor.

Positive results were obtained for anti-SSA and anti-SS-B, RF (128), WR (256), ANA (1:640).
Corresponding author:

Dott.ssa Edit Shahi

Via del Capanno, 21

26900 Lodi

E-mail: editshahi@hotmail.com 
Hypergammaglobulinemia was also detected.

There was no family history of autoimmune or rheumatic disorder, except for her maternal grandfather with ankylosing spondylitis. The girl did not complain of dry mouth or dry eyes. She had no fever.

During the hospitalization in our unit evidence of ocular involvement was obtained as the Schirmer test was positive. Imaging of parotid glands was carried out including ultrasonography which showed a heterogeneous pattern due to multiple hypoechoic focal images within the left gland due to sialoduct ectasia.

The nailfold capillaroscopy revealed only minor unspecific abnormalities.

Laboratory findings were as follows: white blood cell counts $4230 / \mathrm{mm}^{3}$ with normal differentiation, hemoglobin $12.4 \mathrm{~g} /$ dl, platelet count $279000 / \mathrm{mm}^{3}$, ESR 36 $\mathrm{mm} / \mathrm{h}$. There was no abnormality in urea nitrogen, electrolytes, serum transaminases and urine analysis.

There was a mild hypergammaglobulinemia $(23.3 \%$ of $7.8 \mathrm{~g} / \mathrm{dl}$ total proteins). Immunological studies confirmed RF 83 U/L (N 0-15 U/L), anti-SS-A and anti-SSB positive. They showed also C3 $125 \mathrm{mg} /$ dl, C4 22 mg/dl, IgG 2054 mg/dl, IgA 183 $\mathrm{mg} / \mathrm{dl}, \mathrm{IgM} 185 \mathrm{mg} / \mathrm{dl}$, ANA 1:320, LAC antibodies (lupus anti coagulant) negative, ACA (anti cardiolipin antibody) IgG and IgM negative, aDNA negative, ANCA (Anti-neutrophilic cytoplasmic antibodies) negative.
Viral serology for Toxoplasma, measles and Cytomegalovirus, and the rapid test for Epstein-Barr virus resulted negative.

The patient underwent a minor salivary gland biopsy under local anesthesia. Histopathologic examination revealed sialoduct ectasia and focal periductal lymphocytic infiltrate (Fig. 1).

She was diagnosed as having primary Sjögren syndrome class IV.

The patient has been closely followed up for a 6-month period, with clinical features and laboratory values remaining stable. Then, symptomatic treatment with hydroxychloroquine was performed for recurrent arthralgias.

\section{DISCUSSION}

Sjögren syndrome (SS) is an autoimmune disease predominant in females and affects patients in the fourth and fifth decades of their life (1).

It is very infrequent in childhood (2). Ostuni et al. (9) reported that the prevalence of juvenile primary Sjögren syndrome in their series was $5.5 \%$. In most studies the mean age of pediatric patients with primary SS is 9.7 years, and $77 \%$ of them are female (6-9).

The criteria for diagnosing SS are:

a) ocular symptoms;

b) oral symptoms;

c) ocular signs (keratoconjunctivitis sicca);

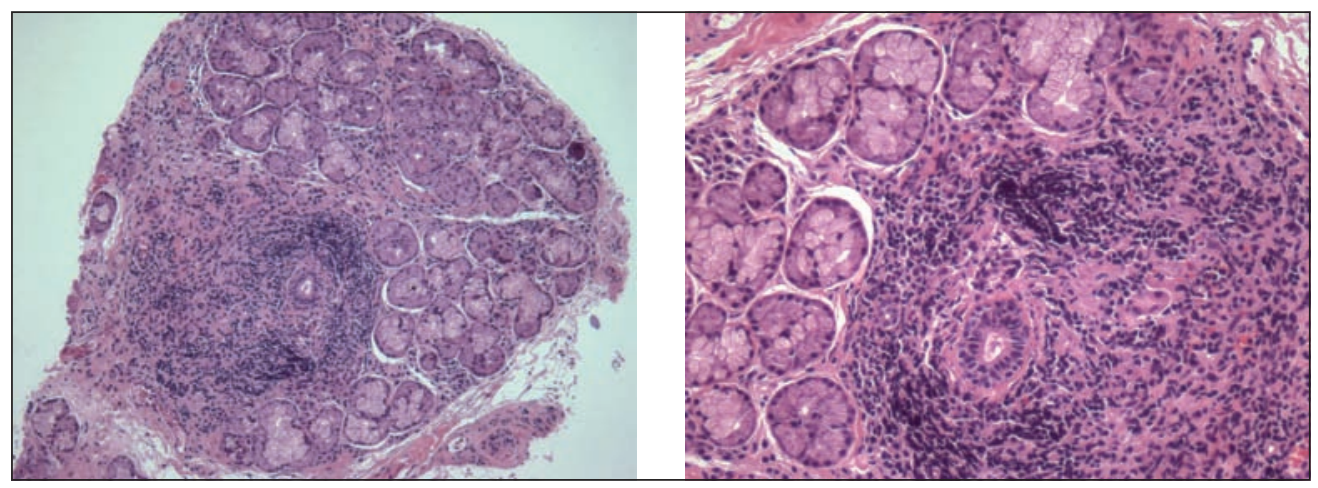

Figure 1 - Histopathologic appearence of a minor salivary gland biopsy showing marked periductal lymphocytic infiltrate (hematoxylin-eosin, original magnification 10x and 20x). By courtesy of Dr. Parafioriti, Department of Pathologic Anatomy, G. Pini Hospital, University of Milan, Italy. 
d) focal lymphocytic sialoadenitis by minor salivary glands biopsy;

e) instrumental evidence of salivary gland involvement;

f) presence of SS-A or SS-B autoantibodies.

Diagnosis of primary Sjögren syndrome requires 4 out of 6 criteria $(10,11)$. Our patient satisfied 4 of these criteria; she did not have oral and ocular symptoms (dry mouth or dry eyes).

Parotid enlargement is present in $74 \%$ of pediatric primary SS patients and is the most common sign at presentation.

Our patient did not exhibit swelling of the parotid glands, although, through ultrasonography the presence of sialoduct ectasia was found.

In children other causes of parotitis include: mumps, streptococcal, staphylococcal and viral infections, such as Epstein-Barr virus and cytomegalovirus, excluded in our case (12-13). Symptoms of dry mouth, which are present in $64 \%$ of the cases, were lacking in our patient.

Oral symptoms are the most common initial manifestation in adults affected with primary SS, but these symptoms usually develop later in childhood.

The incidence of symptoms or signs of eye involvement in the literature is $72 \%$ (3, 14). Ocular symptoms in our patient were absent. However, signs of eye involvement were evident in the form of a positive Schirmer test.

Hypergammaglobulinemia is common in adult Sjogren's syndrome and there is an association between adult Sjogren's syndrome and hypergammaglobulinemic purpura of Waldenström. In literature few cases of hypergammaglobulinemia of Waldenström have been described in childhood (15). Our little patient showed mild hyper-gammaglobulinemia and purpuric manifestation.

Nevertheless the clinical and laboratory features led us to exclude an association between the two syndromes.

A review of the literature revealed that pos- itivity for anti-SS-A (74\%) and anti-SS-B $(65 \%)$ and antinuclear antibodies $(73 \%)$ constitute the most common serologic findings in children with primary SS $(3,14)$. Also in our little patient serologic samples supported the diagnosis of SS, confirmed later by the biopsy of the minor salivary gland.

\section{CONCLUSIONS}

Sjögren syndrome is a rare condition in childhood. It has a wide clinical and immunologic spectrum and may progress from an exocrinopathy to a systemic disease with a variety of extraglandular manifestations and associated autoimmune disease (juvenile arthritis, systemic lupus erythematosus, mixed connective tissue disease). Furthermore, SS patients are at a higher risk of malignant lymphoma (16).

Treatment of SS in children depends on the severity and extent of the symptoms and clinical manifestations.

Symptomatic treatment for sicca symptoms, including artificial tears, salivary substitutes and systemic sialogogues, relieves the symptoms and prevents local infectious complications.

Many studies showed that hydroxychloroquine may be useful in treating arthralgias, myalgias and asthenia in Sjögren patients (11, 17-19). Corticosteroids or other immunosuppressive agents should be reserved for cases showing evidence of organ damage, significant leukopenia or severe clinical manifestations $(9,20)$.

In conclusion, the juvenile Sjögren's syndrome could be probably underdiagnosed (21).

Clinical manifestations in children might be different from the adult form. More data on a larger number of pediatric patients are necessary to confirm it.

Aspecific findings as arthralgia and purpura in children or adolescents should alert the clinicians for the possible diagnosis of juvenile Sjögren's syndrome. 


\section{SUMMARY}

Sjögren-Larsson syndrome (SLS) is an autoimmune disease, uncommon in childhood. We report a case of SLS in a 10-year-old girl with a history of tumor, calor and rubor in the back of her toes almost every month, which resolved in 4-5 days without therapy. She did not complain of dry mouth or dry eyes. The laboratory findings showed high inflammation markers, rheumatoid factor $128 \mathrm{IU}$, Waaler-Rose 256 IU, anti nuclear antibody (ANA) 1/640, SSA (anti Sjögren antigen A) and SSB (anti Sjögren antigen $B$ ) positive and hypergammaglobulinemia. The Schirmer's test resulted to be pathologic, the ultrasonography images and biopsy of minor salivary glands revealed focal periductal lymphocytic infiltrate and sialoduct ectasia class IV of juvenile Sjögren syndrome.

The juvenile Sjögren syndrome is frequently under-diagnosed. Clinical manifestations in children might be different from the adult form, although laboratory findings may be similar to those found in adults.

Parole chiave: Sindrome di Sjögren, antigene anti Sjögren, anti SS-A, anti SS-B.

Key words: Sjögren syndrome, anti Sjögren antigen, anti SS-A, anti SS-B.

\section{REFERENCES}

1. Neville B, Damm DD, Allen CM, Bouquot JE. Salivary gland pathology. In: Oral and maxillofacial Pathology. 2nd ed. Philadelphia: WB Saunders, 2002; 401-4.

2. Cimaz R, Casadei A, Rose C, Bartunkova J, Sediva A, Falcini F, et al. Primary Sjögren syndrome in paedriatic age: a multicenter survey. Eur J Pediatr 2003; 162: 66-5.

3. Nikitakis NG, Rivera H, Lariccia C, Papadimitriou JC, Sauk JJ. Primary Sjögren syndrome in childhood: report of a case and review of the literature. Oral Surg Oral Med Pathol Oral Radiol Endod 2003; 96: 42-7.

4. Fox R. Sjögren's syndrome. Lancet 2005; 366 : 321-31.

5. Manoussakis MN, Moutsopoulos HM. Sjögren's syndrome: autoimmune epithelitis. Baillieres Best Pract Res Clin Rheumatol 2000; 14: 73-95.

6. Anaya J, Ogawa N, Talal N. Sjögren's syndrome in childhood. J Rheumatol 1995; 22: 11528.

7. Bartunkova J, Sediva A, Vencovsky J, Tesar V. Primary Sjögren's syndrome in children and adolescents: proposal for diagnostic criteria. Clin Exp Rheumatol 1999; 17: 381-6.

8. Rocha G, Kavalec C. Sjögren's syndrome in a child. Can J Ophthalmol 1994; 29: 234-7.

9. Ostuni PA, Ianniello A, Sfriso P, Mazzola G, Andretta M, Gambari PF. Juvenile onset of primary Sjögren's syndrome: report of $10 \mathrm{ca}-$ ses. Clin Exp Rheumatol. 1996; 14: 689-93.

10. Vitali C, Bombardieri S, Jonsson R, Moutsopoulos HM, Alexander EL, Carson SE, et al. Classification criteria for Sjögren's syndrome. A revised version of the European criteria proposed by the American-European Consensus Group. Ann Rheum Dis 2002; 61: 554-8.

11. Vitali C, Bombardieri S, Moutsopoulos HM, Coll J, Gerli R, Hatron PY, et al. Assessment of the European classification criteria for
Sjögren's syndrome in a series of clinically defined cases: results of a prospective multicentre study. The European Study Group on Diagnostic Criteria for Sjögren's Syndrome. Ann Rheum Dis 1996; 55: 116-21.

12. Flaitz C. Parotitis as the initial sign of juvenile Sjögren's syndrome. Pediatric Dent 2001; 23: 140-2.

13. Mandel L, Suattanont F. Bilateral parotid swelling: a review. Oral Surg Oral Med Oral Pathol Oral Radiol Endod 2002; 93: 221-37.

14. Civilibal M, Canpolat N, Yurt A, Kurugoglu S, Erdamar S, Bagci O, et al. A child with primary Sjögren syndrome and a review of the literature. Clin Pediatr 2007; 46: 738-42.

15. Martini A, Ravelli A, Viola S, De Stefano P. Hypergammaglobulinemic purpura in childhood. Report of two cases and review of the literature. Helv paediatr Acta 1988; 43: 22531.

16. Ioannidis JP, Vassiliou VA, Moutsopoulos HM. Long-term risk of mortality and lymphoproliferative disease and predictive classification of primary Sjögren's syndrome. Arthritis Rheum 2002; 46: 741-7.

17. Singer NG, Tomanova-Soltys I, Lowe R. Sjögren's syndrome in childhood. Curr. Rheumatol Rep 2008; 10: 147-55.

18. Fox RI, Dixon R, Guarrasi V, Krubel S. Treatment of primary Sjögren's syndrome with hydroxychloroquine: a retrospective, open-label study. Lupus 1996; (Suppl. 1): 31-6.

19. Tishler M, Yaron I, Shirazi I, Yaron M. Hydroxychloroquine treatment for primary Sjögren's syndrome: its effects on salivary and serum inflammatory markers. Ann Rheum Dis 1999; 58: 253-6.

20. Moutsopoulos NM, Moutsopoulos HM. Therapy of Sjögren's syndrome. Springer Semin Immunopathol 2001; 23: 131-45.

21. Stiller M, Golder W, Biedermanecondary Sjn T. Primary and secondary Sjögren's syndrome. Clin Oral Investig 2000; 4: 176-82. 